\title{
Pedagogy in Speaking: Challenges Addressed by Teacher-Student in the ESL Context
}

\author{
Md. Kawser Ahmed*
}

Department of English, Z. H. Sikder University of Science \& Technology, Madhupur, Kartikpur, Bhedergonj, Shariatpur, Bangladesh

Corresponding Author: Md. Kawser Ahmed, E-mail: kawser.zhsust@gmail.com

\section{ARTICLE INFO}

Article history

Received: November 23, 2017

Accepted: January 23, 2018

Published: May 01, 2017

Volume: 7 Issue: 3

Advance access: March 2018

Conflicts of interest: None

Funding: None

\begin{abstract}
Teaching speaking is perhaps one of the major challenges for teachers teaching in English as a Second Language (ESL) classroom environment. Like writing, speaking is not linear and easy approach to ensure the best utilization among learners. Since speaking is a real life event and face to face conversation, it needs more sophisticated care, practice oriented session for the students and effective means to implement it in the ESL situation. Even language experts often grope to outline effective and mediocre way to help learners have a good understanding in speaking. This paper attempts to delineate the focal points where teachers and students face problems in teaching and learning speaking. It immensely chalks out with methodological study, qualitative data analysis and the underlining factors ESL teachers face enormously in the pedagogy of speaking for second language learners. My paper will outline the pedagogical tenets of speaking in the realistic non-native set ups and diagnose the impediments faced by learners when they are supposed to speak and by teachers when they teach speaking for their students.
\end{abstract}

Key words: Challenges, Conversation, ESL, Impediments, Methodological, Pedagogical

\section{INTRODUCTION}

Speaking is a conversational activity that requires both transactional and interactional approach for ensuring its effectiveness and smooth performance. Pedagogy in speaking is interdependent on how teachers adopt the ways to encourage students in speaking, how they implement their plans and procedures in classroom environment and why they face complexity in teaching speaking. Teaching speaking like other skills requires systematic procedures and strategic ways, though in many cases it becomes almost impossible to execute all fixed plans and procedures in real life speaking environment. Speaking unlike reading and writing happens in real life settings where speaker A produces utterances based upon particular topics or situations and speaker B in the first case tries out to understand the utterances produced by the speaker A and then responds to them chronologically. "Of all the four skills (listening, speaking, reading and writing), speaking seems intuitively the most important: people who know a language are referred to as 'speakers' of that language, as if speaking included all other kinds of knowing; and many if not most foreign language learners are primarily interested in learning to speak" (Penny Ur, 1996:120). The ESL context and the pedagogy of speaking are not a new phenomenon rather they get used to explore new challenges for language teachers. The language experts involving in teaching speaking must admit that they are flooded with linguistic gap where teachers desire to initiate the speaking sessions which are not spontaneously functioned by stu- dents. Many non-native teachers consider this activity as an unwanted lesson because they are required to speak in target language with students which very often seem to be a form of reluctance and a kind of anxiety. Blaming students from this perspective regarding pedagogical activity in speaking would be unjustified and baseless because many non-native teachers of English skip speaking and they encourage learners to focus on working out grammatical drills and exercises, reading comprehension followed by question-answer section and writing composition on numerous topics which are considered as a yardstick of performance and marker of qualification. What Bygate (1987) refers to the 'motor-receptive' skills is appropriate for the ESL learners which includes features of sounds, sound patterns and structures of second language. In the speaking pedagogy, the teacher stresses on pattern practices, development of pronunciation work and other relevant things (McDonough and Shaw, 2003: 135-136). It is a usual picture to be seen that most of the ESL teachers consider teaching speaking as an additional pressure and a form of burden in their smooth language teaching profession. Students understanding their teachers' impression about teaching speaking find a good scope to be demotivated in learning and communicating in English language and they almost remain forgettable and ignorant about this essential skill throughout their academic life.

Thornbury (2007:100) identifies that the processes of developing speaking skills comprise of three stages which are as follows: 
- Awareness: Teachers implant ideas that learners are entirely aware of the features of the use of target language which is used as a channel of communication, conversation and commitment of something.

- Appropriation: The features of target language ensure appropriation and integration into the language the learners use for day to day conversation.

- Autonomy: In turn, learners earn autonomy and capacity to use those features of language in real life situation like interview, social interaction and classroom environment.

In this paper, an analysis will be done from the backdrop of pedagogical perspective of teaching speaking with theoretical discussion and survey work done in different ESL contexts where speaking is taught in an orthodox style. In addition, I will explore why the ESL teachers and students address obstacles in teaching speaking in real life classroom, what could be the probable initiatives for speaking trainers and speaking trainees and how the ESL teachers and students will adjust themselves in this type of skill. This paper will be a reliable document in which researchers can understand the possible limitations in implementing pedagogical activities of speaking and thus they will have a clear perception about the ESL teaching-learning environment.

\section{TEACHING FRAMEWORK IN SPEAKING: A PRAGMATIC SCENARIO IN ESL CLASSROOM}

Turning to the practical scenario of classroom in the ESL context, it can be identified that the language practitioners and teachers often fail to materialize the actual purpose of speaking because non-native teachers focus more on accuracy than fluency, more on grammatical correctness and structure based sentences than natural communication and more on teacher-oriented classroom than student-oriented one. The orthodox and conventional framework of speaking class in the ESL learning environment stamp out the authentic goal of teaching and learning of speaking. What we experience in the non-native speaking context is a mere attempt of imitating the native speakers and committing a few techniques regarding the pedagogy of speaking. It will be more pragmatic and authentic, as I draw some examples, discussions and explanations in using techniques for speaking, if I mention role-play, simulation, demonstration and life-experience in our daily conversation from different language scholars and experts. The comparative study they made on their researches and investigations will help us understand genuine picture of what procedures teachers apply to make their students well-conversant in a foreign language, though the discussion will show us the real scenario of a language classroom. A language teacher needs to pay attention on distinctive features of speaking to make his/her learners more communicative and natural in speaking.

"If students want to be able to speak fluently in English, they need to be able to pronounce phonemes correctly, use appropriate stress and intonation patterns and speak in connected speech. But there is no more to it than that. Speakers of English-especially where it is a second language-will have to be able to speak in a range of different genres and situations, and they will have to be able to use a range of conversational and conversational strategies. They will need to be able to survive in typical functional exchanges, too" (Harmer, 2001:343).

What Harmer (2001) suggested about the perfection of speaking bears an entirely dissimilar practice and presentation in the ESL context. Teachers concentrate on one sided discussion in the classroom rather than learner autonomy, consider speaking as barrier to struggle with phonetics, phonology, phoneme and morpheme and prefer to conduct with the principles of Grammar-Translation Method where reading literature and writing with exactness are the focal points of teaching-learning. "Yet some of these same teachers make little attempt to teach pronunciation in any overt way and only give attention to it in passing. It is possible that they are nervous of dealing with sounds and intonation; perhaps they feel they have too much to do already and pronunciation teaching will only make things worse" (Harmer, 2001:248).

Out of many constraints in the arena of speaking, sticking to the practice of nativity frustrates the development of pedagogical accomplishment in speaking class. Students are the obedient imitators of their teachers who are sometimes called "teaching aid", "language model" and "comprehensible input" (Harmer: 2001). Students have best intention to implement what their teachers attempt inside the classroom and how their teachers apply in the speaking class. They strictly follow what their teachers instruct and sincerely perform what assignment is assigned upon them. Upon this situation, shabby performance of speaking results in great disaster and poor pronunciation leads them to the habit formation of adopting wrong pronunciation which happen because teachers' teaching strategies and teaching techniques are reinforced by first language.

\section{ASSUMED BARRIERS IN SPEAKING: SOME OUTLINES FOR ESL TEACHERS}

Teachers and students have to undergo through a series of tremendously pressurized and highly critical stages of teaching speaking in the ESL context. The language teachers face a great deal of difficulty in initiating speaking among the ESL learners who very often have a sense of fear, confusion and misconception about speaking. McDonough and Shaw cited that Richards and Rogers (2001:161) mentioned the four characteristics of communicative view of language which are as follows:

1. Language is a system for the expression of meaning

2. The primary function of language is for interaction and communication

3. The structure of language reflects its functional and communicative uses

4. The primary units of language are not merely its grammatical and structural features, but categories of functional and communicative meaning as exemplified in discourse.

\section{Deficiency in Mutual Interaction and Communication}

The ESL teachers who are directly or bi-directly involved in the speaking pedagogy of English language need to con- 
centrate what Richards and Rodgers (2001:161) showed in the discussion mentioned above. ESL teachers consider speaking is like other skills such as reading and writing where committing some grammatical structures, memorizing a great stock of vocabulary and implementing them on test papers. These concepts regarding speaking in the ESL context frustrate the flourish of this skill where there lacks a strong participation, interaction and communication among learners. If we look at the second language scenario, we can easily understand that most of the learners are reluctant to demonstrate themselves before audiences. Neither they speak what they nurture in their mind nor they participate and motivate other peers to speak openly without indulging any kind of flickering mentality and neurotic presentation. "Students are often reluctant to speak because they are shy and are not predisposed to expressing themselves in front of other people, especially when they are being asked to give personal information or opinions. Frequently, too, there is a worry about speaking badly and therefore losing face in front of their classmates" (Harmer, 2001:345).

\section{Dominance of Teacher in the ESL Speaking Context}

Generally speaking, the non-native teachers have an ingrained tendency to exercise dominance over learners and they impose best efforts to materialize what intention they plan in the language learning environment. "That is, the teacher usually has the power to determine the topics, distribute the turns, give feedback, and ask most of the questions, among other things" (Nunan, 2003). Teachers act like authority and the only determiner regarding any context of language learning where learners are inborn subservient to obey what is ordained and predestined by teachers.

"On most training courses a distinction is made between student talking time (STT) and teacher talking time (TTT)........it is the concern to maximize the former that leads many teachers to use pair and groupwork; it has been assumed that on the whole we want to see more STT than TTT, since, as trainers frequently point out to their student teachers...." (Harmer, 2001:117-118). Language indulgence plays a great role in motivating learners because they need to understand their worth and overcome complexity they face in speech perception and speech production. In addition, humanistic learning permits teachers to give more time what learners like to share before audiences and encourages them to sacrifice teaching tenacity and temperance to ensure confidence and positive feedback upon speaking.

\section{Inefficiency of Applying Educational Technology in Classroom}

The surge of technology and its tremendous impact influences speaking in the ESL context. Teaching and technological aids especially in the arena of speaking and listening are essentially determined by modern technology. The International English Language Testing System (IELTS) and Teaching of English to Speakers of Other Language (TOEFL) are conducted with modern equipment of technology to ensure smoothness and fairness of exam. It is indeed a matter of pity to learn that the deficiency of budget for education, lack of fixed policy in the arena of national curriculum and sense of negligence are the essential factors which help ESL teachers not to have proficiency in the application of educational technology and software. The ESL classroom demonstrates the seating arrangement for students and teachers, hanging of blackboard or whiteboard and registers by which strict policy of attendance is maintained. It is unusual to say teachers show their weakness to cope up with modern technology and thus they cannot be able to ensure standard speaking practice because they require to operate electronic devices and computer-assisted materials. Computer-assisted language learning (CALL) is closely related to many other disciplines and the computer. As a tool to aid teaching and learning, CALL is often subsumed within them. For example, CALL has become increasingly integrated into research on and the practice of general skills of reading, writing, speaking and listening...." (Nunan, 2003:248). The ESL teachers are not readily accustomed to habituate them with computer-assisted language learning (CALL) rather they teach 'general skill' speaking in a traditional set up, though it demotivates the pedagogy of speaking.

"If you walk into some classrooms around the world, you will see fixed data projectors, interactive whiteboards (IBWs), built-in speakers for audio material that is delivered directly from a computer hard disk (rather than from a tape recorder), and computers with round-the clock Internet access" (Harmer, 2001: 175).

Jil and Charles Hadfield (2003a and b) showed technological pyramid naming as "Reversed resources pyramid" which is as follows:

Language laboratories, videos,

computers, Powerpoint

Cassette recorders, OHPs,

photocopiers

Whiteboards, books

Paper and pens

Blackboard

Nothing

Figure 1: Reversed resources pyramid

It can be understood the "Reversed resources pyramid" the bottom of the pyramid is not evenly helpful for language learning because it denotes no availability of language materials, whereas the topper part of pyramid is conveniently conducive to language learning as it is abundant with available essentials for smooth conduct of language teaching and learning.

\footnotetext{
Absence of Speaking Techniques among ESL Teachers

Speaking techniques are the markers by which teachers can measure what learners speak in an emergent situation and how learners present topics before audiences. Regarding speaking techniques, I can mention role-plays, simulations
} 
and oral testing which are determined by the ESL teachers in any conversational setting.

- Role-play: Role-play is a type of acting in a real life situation initiated by teacher for students will not feel comfortable to behave like the real people. Nunan $(2003,57)$ gave a realistic example such: “......one student plays a tourist telephoning the police to report his wallet stolen. The other plays the role of police officer trying to help the tourist file a report". In role play, learners are encouraged to use target language because it resembles the real life situation.

- Simulations: Simulations are broader to what is done in role play in actual setting of conversation. Nunan (2003:57) talks about "props" and "documents" which represent real life goods for performance between two different persons where one is customer and other one becomes shopkeeper. "In simulations the individual participants speak and react as themselves, but the group role, situation and task they are given is an imaginary one. For example: You are the managing committee of a special school for blind children. You want to organize a summer camp for the children, but your school budget is insufficient. Decide how you might raise the money" Ur (1996:132).

- Scale of Oral Testing Criteria:

The ESL teachers are not concerned about the performance of speaking in any classroom setting and thus they are not interested in measuring students' speaking performance maintaining the scale of oral test. Teachers speak in the classroom by mingling target language and native language and remain less careless regarding students' performance.

Following is the scale of oral testing criteria which was based in Israeli exam where candidates are tested on fluency and accuracy and they may get a maximum of five points on each of these two aspects, ten points in all (Ur, 1996:135).

\begin{tabular}{|c|c|c|c|}
\hline \multicolumn{2}{|l|}{ Accuracy } & \multicolumn{2}{|l|}{ Fluency } \\
\hline $\begin{array}{l}\text { Little or no language } \\
\text { produced }\end{array}$ & 1 & $\begin{array}{l}\text { Little or no } \\
\text { communication }\end{array}$ & 1 \\
\hline $\begin{array}{l}\text { Poor vocabulary, } \\
\text { mistakes in grammar, } \\
\text { may have very strong } \\
\text { foreign accent }\end{array}$ & 2 & $\begin{array}{l}\text { Very hesitant and } \\
\text { brief utterances, } \\
\text { sometimes difficult to } \\
\text { understand }\end{array}$ & 2 \\
\hline $\begin{array}{l}\text { Adequate but not rich } \\
\text { vocabulary, makes } \\
\text { obvious grammar } \\
\text { mistakes, slight foreign } \\
\text { accent }\end{array}$ & 3 & $\begin{array}{l}\text { Gets ideas across, but } \\
\text { hesitantly and briefly }\end{array}$ & 3 \\
\hline $\begin{array}{l}\text { Good range of } \\
\text { vocabulary, occasional } \\
\text { grammar slips, slight } \\
\text { foreign accent }\end{array}$ & 4 & $\begin{array}{l}\text { Effective } \\
\text { communication in } \\
\text { short turns }\end{array}$ & 4 \\
\hline $\begin{array}{l}\text { Wide vocabulary } \\
\text { appropriately used, } \\
\text { virtually no grammar } \\
\text { mistakes, native-like or } \\
\text { slight foreign accent }\end{array}$ & 5 & $\begin{array}{l}\text { Easy and effective } \\
\text { communication, uses } \\
\text { long turns }\end{array}$ & 5 \\
\hline TOTAL SCORE OUT & & & \\
\hline
\end{tabular}

In summation, ESL teachers face a number of obstacles which impede the progress of the pedagogy of speaking in a non-native context. In this part of the paper, I have attempted to outline those assumed obstacles addressed by the ESL teachers with sufficient examples and mentioning real life experiences. These are the probable barriers which must be dealt with justified technique considering the greater interest of ESL learners.

\section{LITERATURE REVIEW}

I have a great intention to make the citation of what Nunan (2003) discussed about the difficulty of speaking other than three skills such as reading, writing and listening in a plain but thematic language. "Many people feel that speaking in a new language is harder than reading, writing or listening for two reasons. First, unlike reading or writing, speaking happens in real time: usually the person you are talking to is waiting for you to speak right then. Second, when you speak, you cannot edit and revise what you wish to say, as you can if you are writing" (Nunan 2003:48). The pedagogy of speaking what the ESL teachers apply in the language classroom entirely goes against the norms and techniques of English Language Teaching (ELT). If I make an exploration on Nunan's speech, I can identify the phrase "Many people" which here refers to teachers of English as Second Language (ESL) who very often have untenable and strenuous effort to teach speaking among the non-native learners. It is needless to say that speaking is a skill of acquisition to the native speakers where it appears as a skill of learning to the non-native speakers who struggle to assemble words before speech production and speech articulation in a natural process.

I have a strong inclination to refer to "Problems with Speaking Activities" as box heading by Ur (2010:121) where he identified a number of impediments faced by the speakers when teachers are involved in speaking pedagogy. The four identified problems are:

1. Inhibition: Since speaking requires the real-time exposure to an audience, learners remain inhibited what to say in the classroom through foreign language. They unlike native speakers feel the fear of making mistakes when they produce words, think about the reception of criticism from or matter of shyness from audiences' corners and over thought about what the audiences think about him as speakers.

2. Nothing to say: Reticence is the essential quality which is usually found among ESL learners where they feel that they have nothing more to present, share and exchange in the speaking environment. In addition, ESL learners suffer from inferior complexity that they might be wrongly treated after learning their words.

3. Low or uneven participation: The ESL speakers are driven by tendency than by intensity of situation in a real life speaking environment. The greater the participation of speakers in any speaking session, the lesser scope they have to speak before the audiences-it is a wide escape from the speech presentation. The sense of dominance occurs because some speakers speak with 
the maximization of their time while other speakers remain passive and inactive.

4. Mother-tongue use: The ESL speakers' bend to use mother tongue as a channel of communication is the striking factor to come out of the false starts in target language. Speaking in foreign language seems to be 'unnatural' which exposes the unnerving situation among the ESL speakers.

In relation to this discussion, I can draw a relationship where the ESL students face obstructions in the speech production. It can be held that the ESL learners are not enthusiastic and ardent to what they need to present and speak before audiences.

"Tsui's (1996) research what she calls the 'reluctant' speaker in the language classroom revealed five main reasons why learners are unwilling to participate: the students perceive themselves to be at a low proficiency level, they worry about making mistakes and the resultant derision from peers, teachers may be intolerant of silence, turn-taking is uneven across the class and input is incomprehensible" (McDonough and Shaw 1993:142).

In the pedagogy of speaking set by ESL teachers, learners hardly find the implication of motivation which might work as a vitally negative force to articulate better presentation in speaking. ESL teachers do not include abstract things like motivation and positive reinforcement in their course curriculum rather they imitate what they find on books and present them before novice learners in an unmannered way for which they cannot retain their power on sound speaking what is told by Nunan (1999).

"Nunan (1999) suggests that teachers need to be aware that motivation is a consideration in determining whether or not learners are willing to communicate. Clearly the more meaningful the materials and tasks are for the learners involved the better the outcome will be" (McDonough and Shaw 1993:142).

"Ur (1996) develops this further by suggesting that good speaking skills classrooms are ones where learners talk a lot, participation is even, motivation is high and the language is at an acceptable level" (McDonough and Shaw 1993:142).

From the review of literature presented in this section of this article, it can be said that the ESL teachers definitely come across a wide arrays of challenges, though not because of their lack of eagerness, enthusiasm and positive impression to practice target language, which help them to materialize what they have in course content because most of the learners find them as great hurdles to deal with. In addition, the review of literature shows the demotivation what the learners face from their teachers in the articulation of speech in target language and cultural milieu and social backdrops work as catalyst by which learners are bound to fade their impression away, though it does not happen intentionally, it happens based upon circumstances.

\section{METHODOLOGY}

A survey was conducted among 70 ESL university learners at Z. H. Sikder University of Science \& Technology, a private university of Bangladesh where they were asked to fill out the questionnaires furnished with 10 separate questions by which qualitative data were collected followed by analysis of data in pie charts. The questionnaires were distributed among learners irrespective of junior and senior students who shared individual comments acquiring a good sum of experiences regarding speaking by ESL teachers. They were given time, sufficient guidelines and full independency to give their individual judicious opinions based upon five alternative options of a single question. The methodology includes the participation of ESL students in the survey work, collection of data based upon participants' comments and feedbacks from the questionnaire, procedures in which proper approximation of data was done, analysis of data obtained from participants and findings which were presented through pie charts.

\section{RESULTS OF THE STUDY}

In this section of the paper, a set of questions has been prepared for the participants of an ESL speaking class. The participants judiciously answered 10 questions which were presented with five alternative varied answers. This study shows the practical scenario of teaching speaking technique in the ESL classroom indicating what impression the ESL learners have towards the ESL teachers and what performance teachers demonstrate in speaking. In fact, results of the study give specimen picture which might be even poorer in the economically back warded community like the least developed countries (LDCs) where English is taught as second language. The findings were prepared with ten pie charts referring to the questions from questionnaire, how they responded based upon questionnaire and percentage of students' comments on teachers' performance what they experienced in the classroom.

\section{Do ESL Teachers Have Full Practical Knowledge on Speaking While Taking Class?}

Figure 1 describes that $38 \%$ students say that teachers have moderate knowledge indicating an optimum level of speaking for ESL teachers, 19\% students say teachers command sufficient knowledge referring to students are in satisfaction regarding teaching speaking, $17 \%$ students say teachers are not concerned about speaking referring to teachers show negligence to a great extent in teaching speaking, 10\% students say teachers do not have sufficient knowledge pointing out non-native speaking teachers apply substandard follow up of pedagogy in speaking and $16 \%$ students say that teachers have poor knowledge on speaking showing ESL teachers are not well-trained and do not possess in-depth techniques in speaking when they conduct a real life classroom.

\section{Do ESL Teachers Provide Sufficient Guidelines on the Standard Pronunciation?}

Figure 2 shows that $44 \%$ students say that teachers provide moderate guidelines concerning students receive authentic and pragmatic strategies to speak in a real life situation, 20\% students say that teachers provide them with poor guidelines 


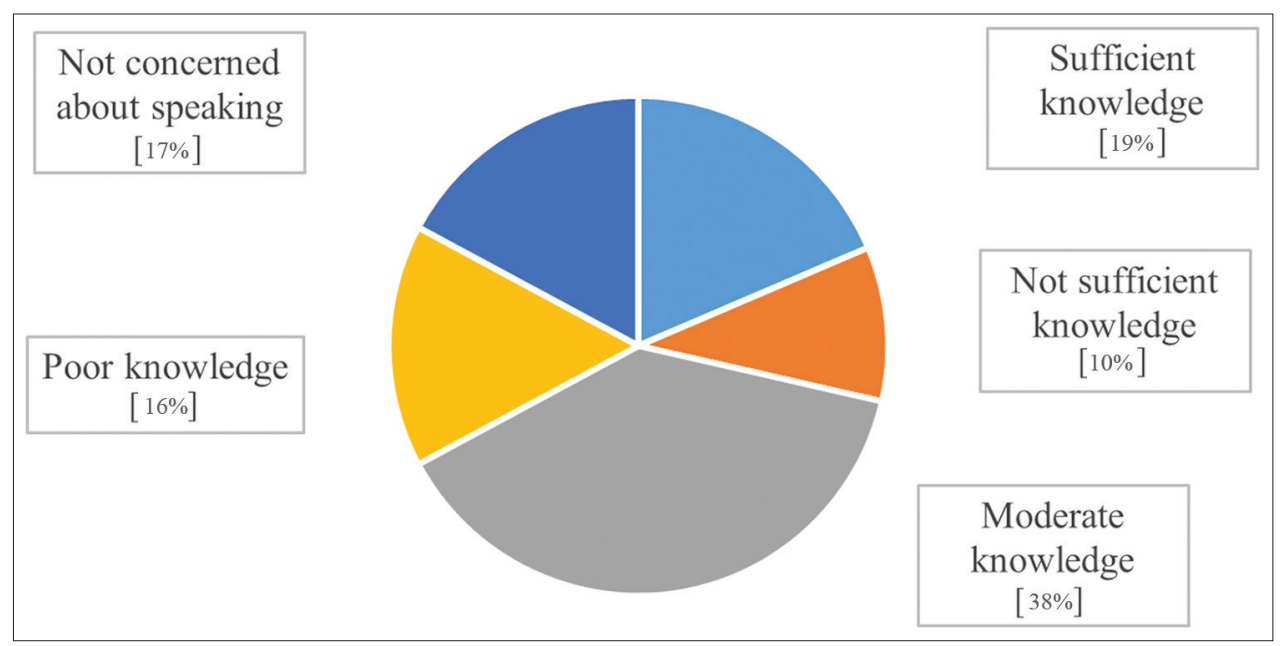

Figure 1. Teachers' full practical knowledge on speaking while taking class

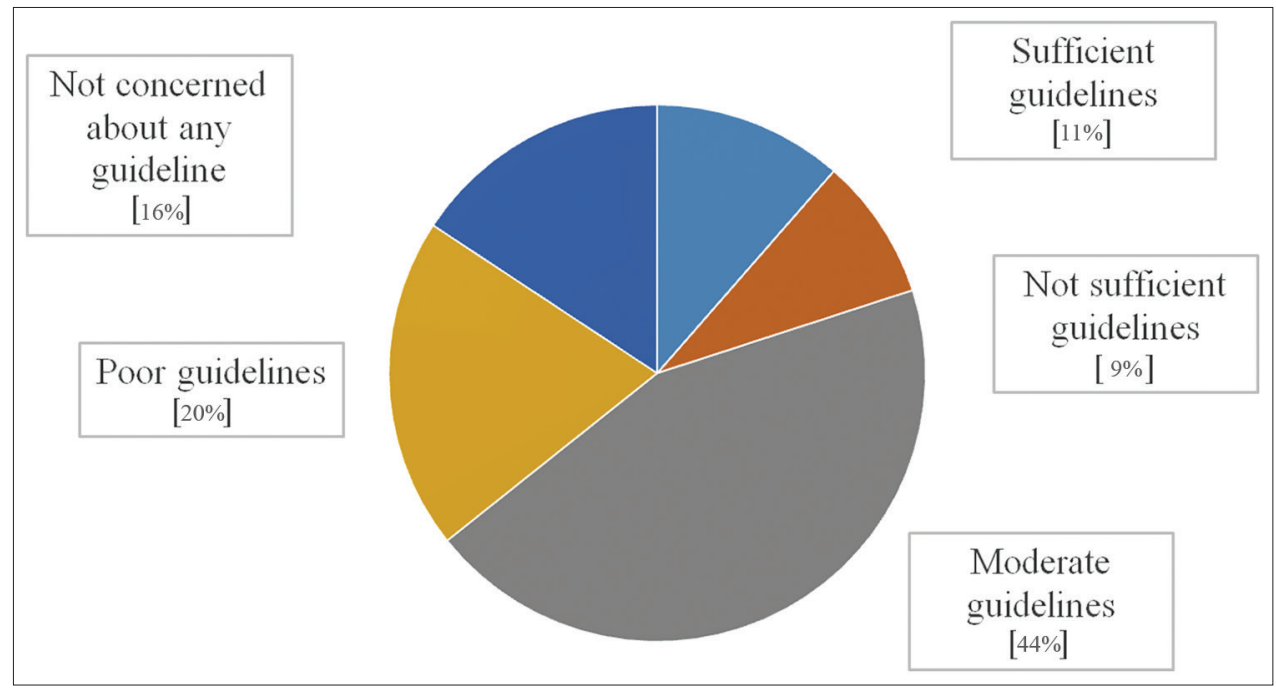

Figure 2. Teachers' sufficient guidelines on the standard pronunciation

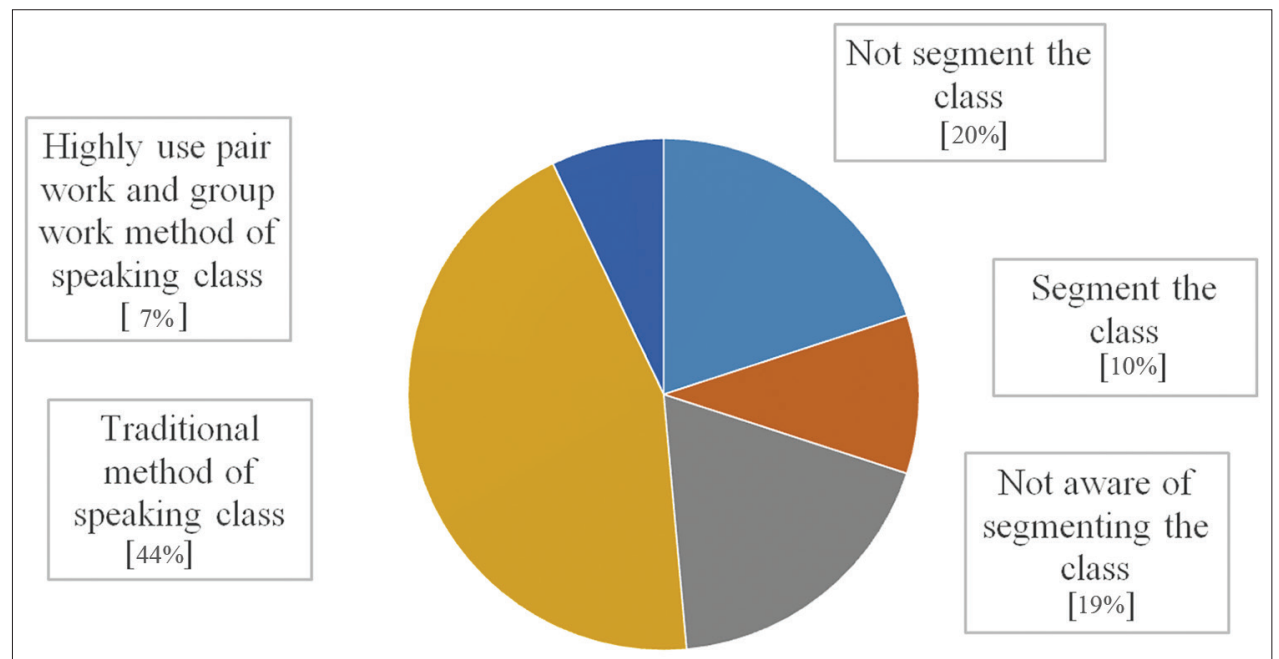

Figure 3. Teachers' guidelines on segmenting the class into pair work and group work for speaking

indicating teachers need to rethink what they instruct to students as a pack of instructions, 16\% students say teachers are not concerned about providing any guidelines referring to teachers use native language in the classroom conniv- ing at target language, $11 \%$ students say that teachers have sufficient guidelines indicating teachers pioneer creative methods to engage students in different types of speaking activities and 9\% students say teachers do not provide any 
guideline showing teachers conduct classroom regardless of putting emphasis on the standard pronunciation.

\section{Do ESL teachers give guidelines on segmenting the class into pair work and group work for speaking?}

Figure 3 describes that $44 \%$ students say teachers use traditional method of speaking class referring to ESL teachers entirely hold the position against phasing classroom into various formats, $20 \%$ students say teachers do not segment the class indicating teachers avoid making effective progress in speaking for ESL learners, 19\% students say teachers are not aware of segmenting the class concluding teachers are bereft of receiving teaching-learning oriented training session, $10 \%$ students say that teachers segment the class summing up teachers and students enroll them on their part in different speaking activities and $7 \%$ students say teachers highly use pair work and group work showing teachers get them out of dais and introduce simulations and role play acts.

\section{Do ESL teachers inspire students to speak in the target language in the classroom?}

Figure 4 describes that $40 \%$ students say teachers inspire students to speak in target language referring to students speak less in native language, 30\% students say teachers are indifferent to inspire students to speak in target language indicating teachers use mother tongue while delivering lecture in target language, $13 \%$ students say teachers do not inspire students to speak referring to teachers do not focus on supra segmental like stress, intonation and tone, $10 \%$ students say teachers inspire only best speakers indicating teachers choose only selective students for simulations and peer conversation and $7 \%$ students say teachers demotivate to use the target language pointing out teachers lack sufficient speak-

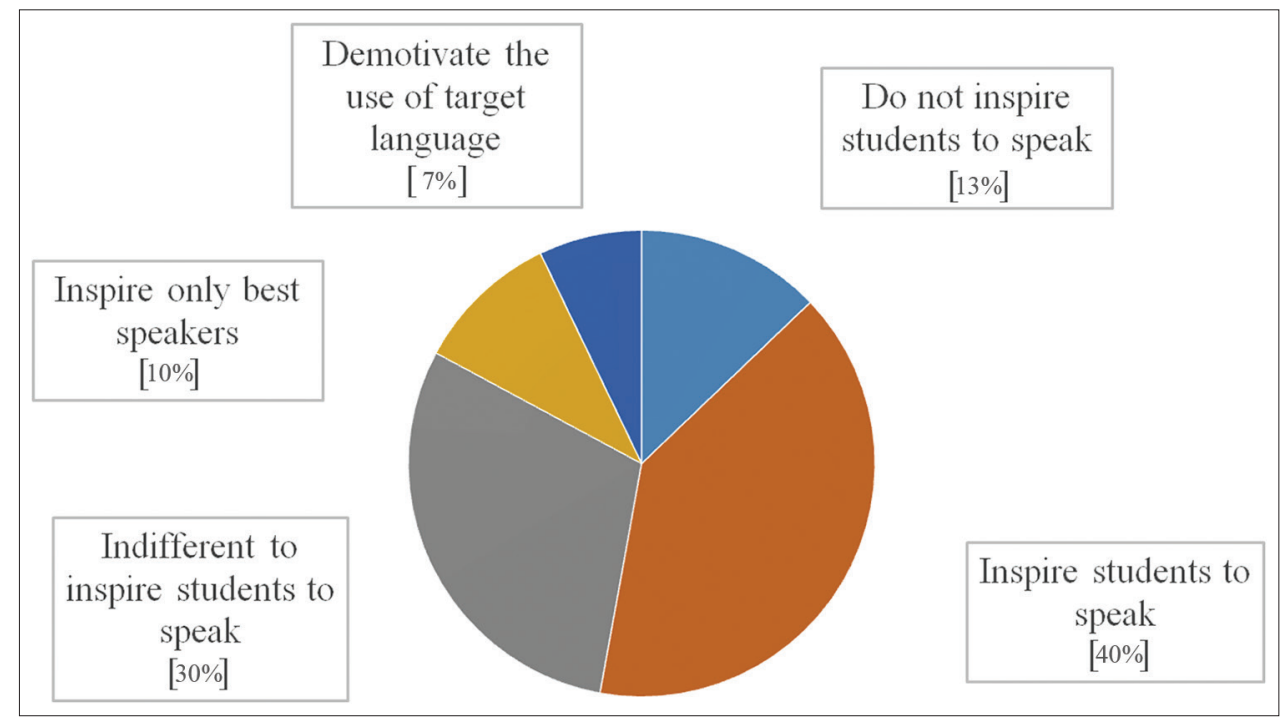

Figure 4. Teachers' inspiration to students to speak in the target language in the classroom

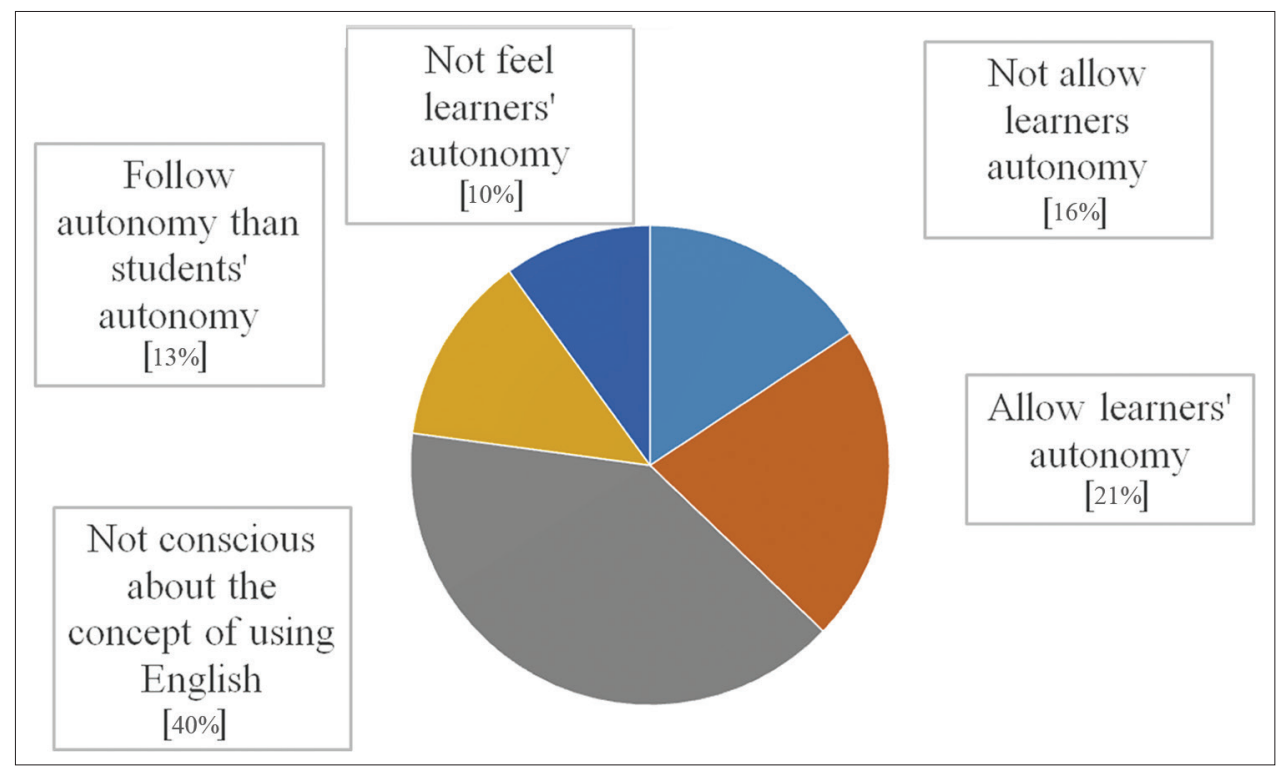

Figure 5. Teachers' encouragement of learners' autonomy to use English in the classroom 


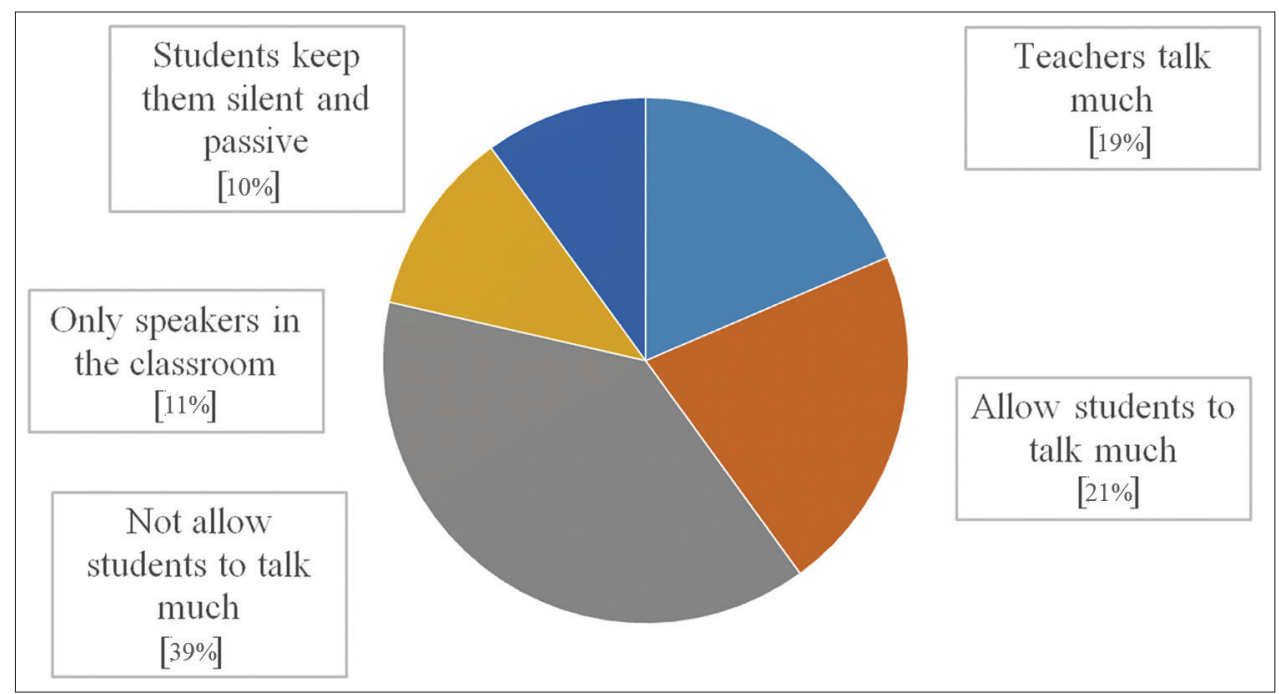

Figure 6. Percentage of teachers' talk or students' talk in the speaking classroom

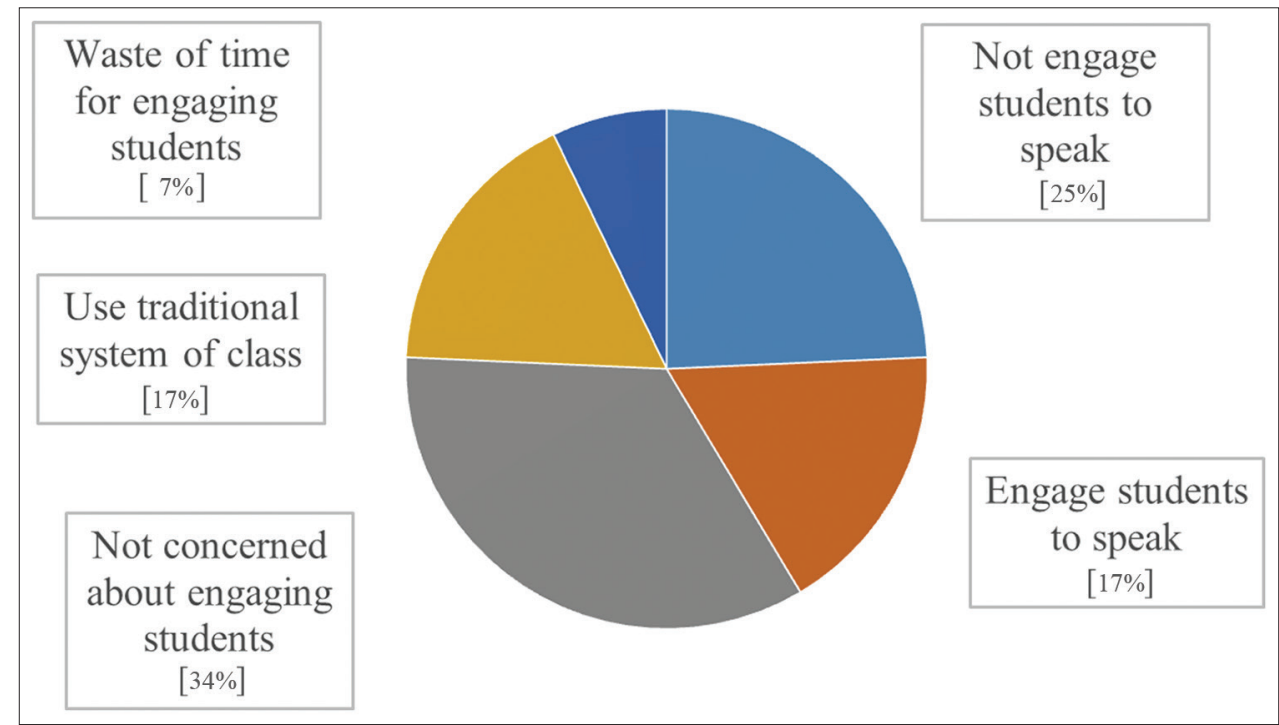

Figure 7. Engaging students by teachers in mutual discussion or conversation in speaking

ing skills and feel hesitated to use target language for teaching-learning.

\section{Do ESL teachers ensure learners' autonomy to use English in the classroom?}

Figure 5 describes that $40 \%$ students say teachers are not conscious about the concept of using English referring to teachers remain disinclined to introduce target language in classroom, 21\% students say teachers allow learners' autonomy indicating teachers ensure democracy and learners' intention and impression towards target language, 16\% students say teachers do not allow learners' autonomy pointing out teachers intend to play authoritative role in classroom, $13 \%$ students say teachers demonstrate autonomous feeling and 'super ego' to restrict students' talk in English and 10\% students say teachers do not feel learners autonomy indicating teachers conceptualize learners' participation is entirely a wastage of time.

\section{How is the percentage of ESL teachers' talk or students' talk in the speaking classroom?}

Figure 6 describes that $39 \%$ students say teachers do not allow students' talk summing up teachers consider language teaching-learning should be confined in a traditional pattern, $21 \%$ students say teachers allow students to talk much meaning teachers feel students' internal and external motivation will work out to use target language in classroom, 19\% students say teachers like to talk much concluding teachers are influenced by traditional pedagogy of teaching, $11 \%$ students say teachers are the only speakers in the classroom ignoring the presence of passive learners and 10\% students say teachers keep students silent and passive in the classroom indicating teachers feel students are entirely incompetent to speak in target language.

\section{Do ESL teachers engage students in mutual discussion or conversation in speaking?}

Figure 7 describes that $34 \%$ students say that teachers are not concerned about engaging students in speaking referring to 
ESL students remain inactive and reticent in classroom, 25\% students say teachers do not engage students in speaking meaning teachers lack adequate skill and managerial competence to segment class for mutual discussion, $17 \%$ students say teachers use traditional method to engage students in speaking highlighting students will be unable to cope up with newly adopted language method and $7 \%$ students say teachers think engaging students in speaking is a wastage of time referring to students are lethargic and dispirited in mutual discussion and conversation.

\section{Does authority impose instructions to let students speak English in all academic stages?}

Figure 8 describes that $33 \%$ students say that teachers follow some guidelines but no way of implementation indicating teachers feel speaking activity might create a sort of absent mindedness among learners, 24\% students say teachers do not follow instructions guided by the authority meaning teachers think they possess insufficient knowledge in speaking pedagogy, 13\% students say teachers do not give any clear instructions pointing out students feel easy and eager to speak in native language than foreign language, 20\% students say teachers take a great care of speaking English referring to teachers possess knowledge in material, syllabus and curriculum development and $10 \%$ students say teachers demotivate students' speaking activity highlighting students deviate from selected point of discussion and poor pronunciation.

\section{Do ESL teachers have weakness to deliver lecture in English language?}

Figure 9 describes that $33 \%$ students say teachers face some obstacles to deliver lecture pointing out non-native teachers

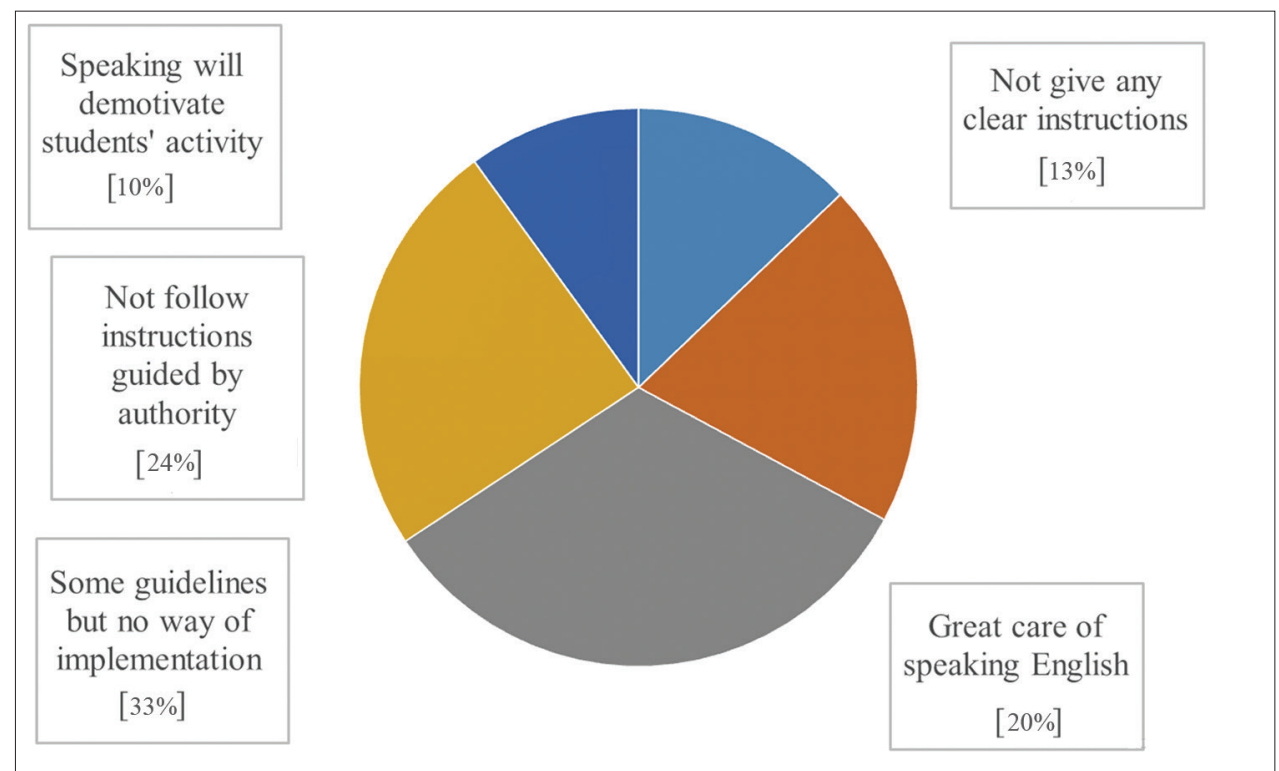

Figure 8. Imposition of instructions from authority to speak English in all academic stages

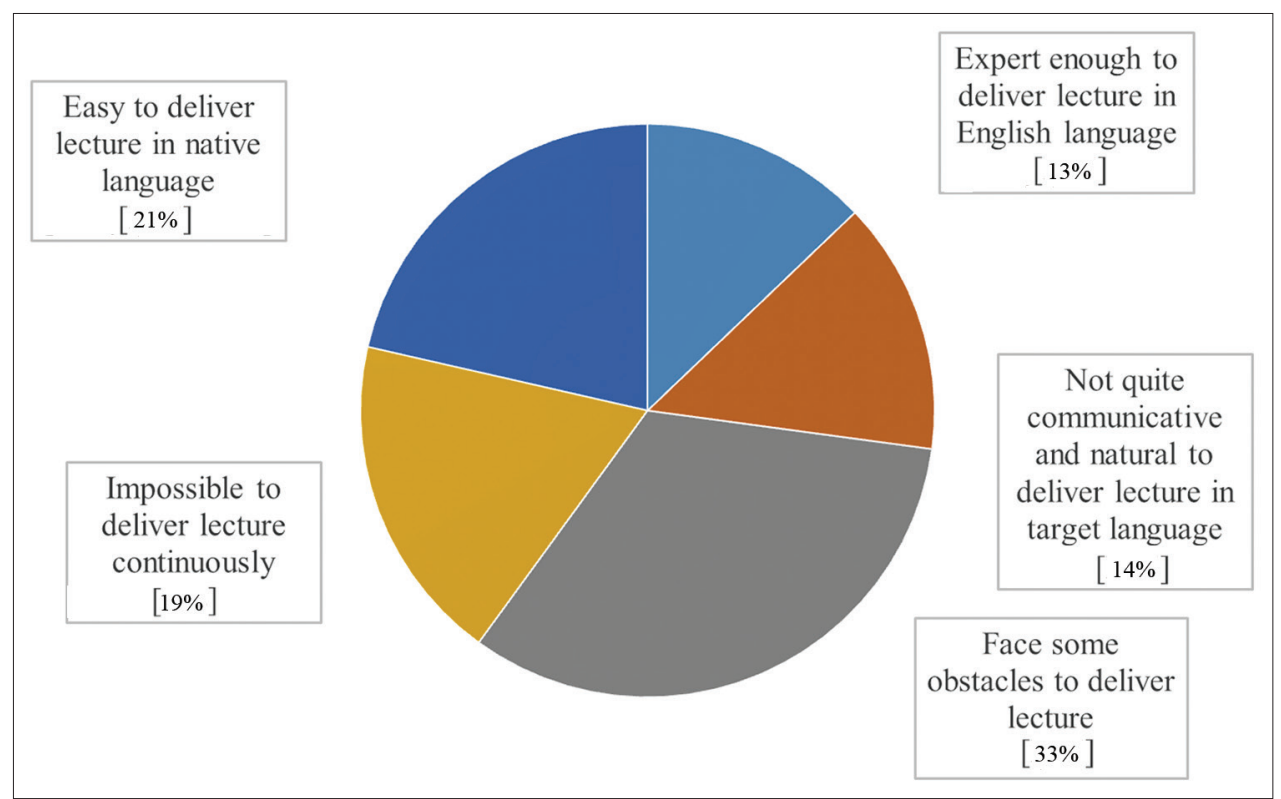

Figure 9. Teachers' weakness to deliver lecture in English language 


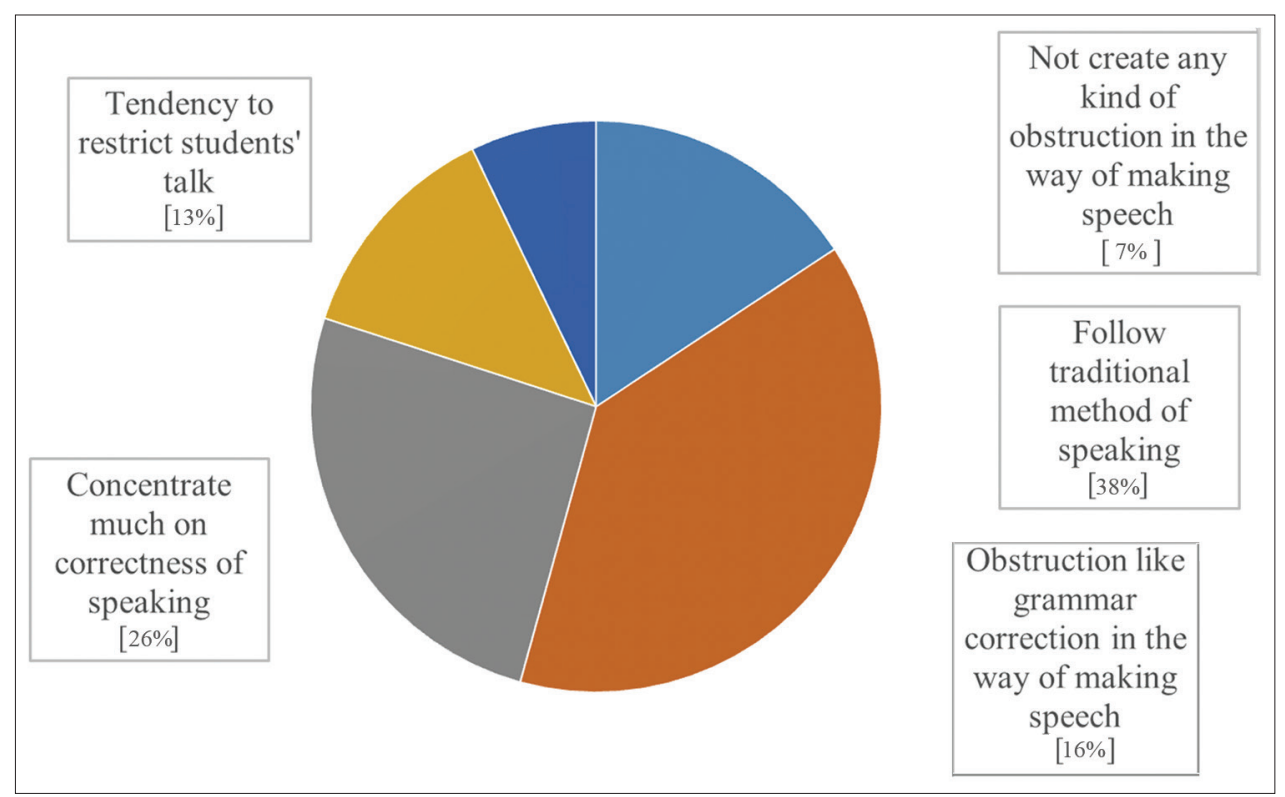

Figure 10. ESL teachers' creation of obstruction while students talk in the classroom

teach in a traditional pattern and deliver lecture in their native langu

age, $21 \%$ students say teachers feel easy to deliver lecture in native language referring to teachers receive standard training and workshop in speaking methodology, 19\% students say teachers feel it impossible to deliver lecture continuously meaning some teachers feel obstructed to speak in English consecutively, $14 \%$ students say teachers are not quiet communicative and natural to deliver lecture indicating teachers apply natural tendency of using native language and 13\% students say teachers are expert enough to deliver lecture in native language referring to teachers use the principles of Direct Method in speaking classroom.

\section{Do ESL teachers create obstruction while students talk in the classroom?}

Figure 10 describes that $38 \%$ students say teachers follow conventional method of speaking meaning teachers are not accustomed to speaking in classroom for they obstruct in the midway students' speaking, 26\% students say teachers concentrate much on the correctness of speaking meaning ESL teachers focus more on accuracy than fluency, $16 \%$ students say teachers create obstruction like grammar correction in the way of making speech meaning teachers feel structural neatness needs to be maintained like writing in speaking, 7\% students say teachers do not create obstruction like grammar correction in the way of making speech referring to teachers say students gradually learn by staging up the staircases of errors and $13 \%$ students say teachers have tendency to restrict students' talk in the classroom indicating teachers disavow learners' autonomy and blockade student in the midst of conversation and discussion.

\section{DISCUSSION}

The qualitative data based upon a survey among tertiary level students expose the realistic picture of pedagogy in speaking, glimpse the lack of teaching technique and outline the probable impediments in the way of executing methodology in the ESL learning context. The participants concerning teaching of speaking what they obtained from real life classroom gave expression of interest through individual opinion. It is highly rational to judge that participants based points by observing the mode of class taking, teachers' expertise on speaking and implementation of strategy of speaking among ESL learners. It is worth noting that students were inclined to learn speaking along with elaborate elucidation of techniques in speaking and spontaneous inspiration and voluntary support from teachers. "In the communicative classroom, however, interaction is far less teacher-centered and focuses on learners speaking to each other for specific reason in order to achieve a specific outcome" (McDonough and Shaw, 1993:141). It is pathetic to observe that ESL teachers do not foster any silver lining thought to motivate students for interaction or mutual session for speaking. They lose impression about, though it is often called a typical task to inspire students to speak before crowd, speaking and almost fail to overcome abstract hindrances to address them as independent speakers. Teachers have a great tendency to evade the segmentation of classroom into pair and group considering the number of students. They have a good scope to initiate many small sized speaking activities like jigsaw among ESL learners in order to prepare them for facing public speaking and presentation standing on podium. The example of information gap principle applying 'jigsaw' activities can be effective in teaching and learning materials (Geddes and Sturtridge: 1980). What is found from the data analysis is all about the summation of teachers' performance in the real life classroom and students' reactions what teachers are performing and what they should act regarding speaking in ESL context.

\section{CONCLUSION}

The pedagogy of speaking what the ESL teachers follow to dispense speaking among the ESL learners is not free from 
error and drawback within itself. In this paper, I have attempted to show a comparative study where the ESL teachers face problems and how data analysis explicitly show authentic situation of the ESL classroom. All of the data presented in this article are convenient to give out new window of research, understandable picture and practical observation along with data collection and data analysis through many charts. It seems to be convincing that every single question was explained selected from the questionnaire to make readers understand in a clear and easy way. Pie charts have been prepared with numerical figures which were taken from qualitative data based upon questionnaire from the university students in the ESL classroom experience. In spite of having numerous strata of limitations, I believe this research paper will bring out realistic aspects of speaking scenario in the ESL context where teachers and students alike possess different dimensional complexities in the pedagogy of speaking. Researchers can assimilate between what problems learners face and what roles teachers play in teaching speaking among ESL learners. I consider this work will work as remedy in line with solving the impediments faced by both ESL teachers and students in pedagogical work of speaking.

\section{REFERENCES}

Braine, G. (Ed.) (1999). Non-Native Educators in English Language Teaching. Mahwah, NJ:
Lawrence Erlbaum Associates Inc.

Brown, G. and Yule, G. (1993). Teaching the Spoken Language, Cambridge: Cambridge University Press.

Bygate, M. (1987): Speaking, gives a very useful insight into the nature of the speaking skills within a broad pedagogical framework.

C. Richards, J. (2006). Communicative Language Teaching Today. Cambridge University Press.

Crystal, D. (2003). English as a Global Language. Cambridge: Cambridge University Press.

Harmer, J. (1991). The Practice of English Language Teaching. Essex: Longman Group UK Ltd.

McDonough, J. and Shaw, C. (1993). Materials and Methods in ELT: A Teacher's Guide. Blackwell Publishing.

Nunan, D. (1999). Second Language Teaching and Learning. Boston, MA: Heinle \& Heinle.

Nunan, D. (2003). Practical English Language Teaching. The McGraw Hill Companies.

Richards, J.C. and Rogers, T.S. (2001). Approaches and Methods on Language Teaching. Cambridge: Cambridge University Press.

Thornbury, S. (2007). How to Teach Speaking. Harlow: Pearson Education Limited.

Ur, P. (1981). Discussions that Work, Cambridge: Cambridge University Press.

Ur, P. (1995). A Course in Language Teaching. Practice and Theory. Cambridge: Cambridge University Press. 